
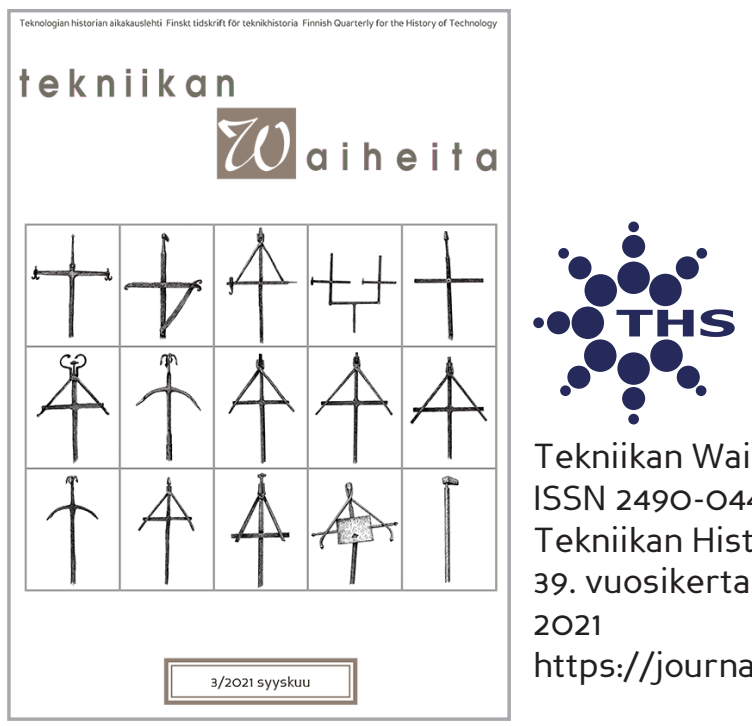

Tekniikan Waiheita

ISSN 2490-0443

Tekniikan Historian Seura ry.

39. vuosikerta: 3

2021

https://journal.fi/tekniikanwaiheita

Teolliset ja varhaisteolliset arkeologiset kohteet Metsähallituksen inventoinneissa

Tapani Tuovinen

To cite this article: Tapani Tuovinen, "Teolliset ja varhaisteolliset arkeologiset kohteet Metsähallituksen inventoinneissa" Tekniikan Waiheita 39, no. 3 (2021): 160-177 https://doi. org/10.33355/tw.110533

To link to this article: https://doi.org/10.33355/tw.110533 


\title{
Teolliset ja varhaisteolliset arkeologiset kohteet Metsähallituksen inventoinneissa
}

\author{
Tapani Tuovinen'
}

\section{Valtion metsähallinnon alkuvaiheet}

Keskiajalla muotoutuva kuninkaan valta pyrki kasvattamaan kaupunkeja, hallintoa ja sotaväkeä ja turvaamaan käyttöönsä resursseja kontrolloimalla ja verottamalla maataloustuotantoa ja luonnonvarojen käyttöä. Maat ja vedet, jotka eivät ikimuistoisen nautinnan perusteella kuuluneet yksityiselle tai yhteisölle, olivat Jumalan, valtion ja kuninkaan omistuksessa. Tämä näkemys perustui italialaiseen oppiin kuninkaan yliomistuksesta, jonka fiskaalista hyödyntämistä erityisesti Kustaa Vaasa kehitti ja lujitti. Kuninkaan regaalioikeudellinen vaatimus koski metsävarojen lisäksi muun muassa tuottoisia kalastuskareja ja malmivarantoja ${ }^{2}$.

Valtion omistamien metsien ja talonpojille kuuluvien yksityisten metsien väliset rajat olivat epäselvät aina isojakoon asti. Vuonna 1757 säädetty isojakoasetus aloitti maanomistusten yhtenäistämisen talokohtaisiksi tontti-, viljelys- ja niittypalstoiksi, ja yhteisesti omistettujen metsien muuttamisen talokohtaisiksi metsäpalstoiksi. Ylimenevä metsä siirrettiin pääosin valtiolle ns. liikamaana käytettäväksi uudisasutukseen³ .

Valtion yliomistusta purettiin vähitellen muuallakin. Valtio luopui yksinoikeudesta malmeihin 1723 ja sen tilalle tuli valtausjärjestelmä, mutta valtio säilytti edelleen hallinnassaan kaivosomistuksia ${ }^{4}$. Toisaalla, kuten yleisvesien kalastusoikeuksissa, valtion erityisoikeudet ovat säilyneet itsenäisen valtion oikeusjärjestelmään asti.

Autonomian aikana metsien käyttöön kohdistuvat paineet ja osin vastakkaiset intressit lisääntyivät. Metsävarojen käytöstä kilpailivat ruukit, vuoriteollisuus ja metsien kotitarvekäyttö. Sahateollisuus ylitti jatkuvasti privilegioissa sallitut hakkuumäärät. Vesisahojen ja uusien höyrysahojen pelättiin tuhoavan Suomen metsät. Teollisuudenhaarojen keskinäinen kilpailu johti 1840-luvulla metsäpoliittiseen kädenvääntöön. Siihen osallistuivat mm. Saimalehden päätoimittaja J.W. Snellman, joka kannatti metsien tehokasta hakkuuta, ja senaatin finanssitoimituskunnan päällikkö L.G. von Haartman, vuoriteollisuusmies ja merkantilisti. Vaikutusvaltaisen von Haartmanin näkemyksen mukaan metsävaroja kuluttavaa sahateollisuutta oli säänneltävä ja valtion metsien hoitoa oli tehostettava. Ymmärrettiin laajasti, että valtion metsähallinto oli saatava järjestetyksi. Vuonna 1851 säädetyllä metsäasetuksella perustettiin väliaikainen metsänhoitolaitos, josta muodostettiin metsänhoitohallitus 1859 . Vuonna 1908 viraston nimeksi annettiin Metsähallitus ${ }^{5}$.

\footnotetext{
${ }^{1}$ Kirjoittaja on rannikkoarkeologian dosentti Oulun yliopistossa ja toimii kulttuuriperinnön erikoissuunnittelijana Metsähallituksen Rannikon Luontopalveluissa.

${ }^{2}$ Inger 1997, 41-43.

3 Jutikkala 1958, 246-259; Talvitie 2013, 64-68.

${ }^{4}$ Bäckström 2015, 28-31.

${ }^{5}$ Parpola \& Áberg 2009, 16-32.
} 


\section{Teollisuusarkeologiset kohteet}

Ruotsin vallan ajan suuret teolliset laitokset - ruukit, lasitehtaat, sahat, kaivokset ja laivanrakennus - olivat pääomavaltaisia hankkeita, joissa käytettiin paljon materiaaleja ja energiaa ja tuotettiin ympäristöön runsaasti sellaisia anomalioita, jotka ovat nyt tai joiden odottaisi nyt olevan näkyvissä arkeologisina jälkinä. Mittavat varhaisteolliset rakennushankkeet ovat aina olleet tiedossa, eikä niitä ole ollut tarpeen löytää niin kuin arkeologisia kohteita yleensä. Ne näyttäytyvät merkityksellisenä teollisuusarkeologisena kulttuuriperintönä, jonka korkea arvotus on ilmeinen. Se, mitä muuta luetaan teollisuusarkeologisten kohteiden joukkoon, riippuu paljolti siitä, miten laajasta ja pääomavaltaisesta tuotannosta puhutaan, millainen aikaraja tuotantotoiminnalle asetetaan ja miten määritellään häilyvä raja teollisen tuotannon ja kansanomaisen kotiteollisen tuotannon välillä. Kotiteollinen käsityö ei, toisin kuin teollisuus, tarvinnut toiminnalleen valtiovallan lupaa, minkä johdosta kotiteollisen tuotannon arkistolähteet ovat niukemmat kuin teollisuustuotannon ${ }^{6}$. Kotiteollisuuden lähdeaineistoa on myös luonnehdittu epätarkaksi ja epätasaiseksi ${ }^{7}$. Pienimuotoinen kotiteollinen toiminta jätti myös ympäristöön vaikeammin havaittavia arkeologisia jälkiä kuin teollisuus.

Metsähallituksen hallinnoimilla mailla ja vesissä on tämänhetkisen tietämyksen mukaan 27000 arkeologista kohdetta, joiden tiedot on tallennettu Metsähallituksen PAVE-paikkatietojärjestelmään ${ }^{8}$. PAVEn tiedot eivät ole täydelliset, vaan Museoviraston Museoverkossa on joukko kohteita, joita ei ole tallennettu PAVEen.

Kohteita koskevat tiedot on suureksi osaksi kerätty Metsähallituksen arkeologien vuosina 2006-2021 suorittamissa inventoinneissa. Inventoitavina ovat olleet Metsähallituksen hallinnassa olevat kiinteistöt ja joiltakin osin sellaiset suojelualueet, joilla Metsähallituksen Luontopalvelut toimii yhteistyössä muun maanomistajan kanssa esimerkiksi luonnonhoidossa. Aineistossa painottuu vahvasti Kansalliseen metsäohjelmaan kuulunut valtion monikäyttömetsien kulttuuriperinnön inventointi 2010-2015. Hankkeessa dokumentoitiin yli 10000 arkeologista kohdetta, joiden ikähaarukka on noin 10000 vuotta?

Seuraavassa tarkasteltavat teollisuusarkeologiset kohteet on poimittu Metsähallituksen valtionmaiden kohteista Arkeologisen kultturiperinnön oppaan ${ }^{10}$ mukaisella tavalla, joka rajaa runsaslukuisen hiilimiilujen kategorian teollisuusarkeologisten kohteiden piiriin. Kohteille ei asetettu muita aikarajoja kuin se, että esihistorialliset kohteet suljettiin pois. Teollisuusarkeologisten kohteiden kysely PAVE-paikkatietojärjestelmästä ei täydellisellä varmuudella tuota kaikkia määritelmän täyttäviä kohteita, sillä paikkatiedon rakenteeseen tehtiin vuonna 2017 muutoksia, joista seuraava tallennustyö on kesken. Kyselyjä yhdistelemällä tietokannasta tuli kaivetuksi esiin 808 teollisuusarkeologista kohdetta (Kuva 1).

\footnotetext{
${ }^{6}$ Kallio 2005.

${ }^{7}$ Virrankoski 1963, 17-20.

${ }^{8}$ Uljas-tietojärjestelmät https://www.metsa.fi/maat-ja-vedet/paikkatieto/paikkatietojarjestelmat/

${ }^{9}$ Taivainen 2016.

${ }^{10}$ Arkeologisen kulttuuriperinnön opas. http://akp.nba.fi/
} 
Kuva 1. Teollisuusarkeologiset kohteet Metsähallituksen PAVE-paikkatietojärjestelmässä.

Kohteiden jakaumat heijastavat paljolti Metsähallituksen inventointien suuntautumista. Kohteista kaikkiaan 627 sijaitsee Metsähallituksen liiketoiminnan ja Metsähallitus Metsätalous Oy:n hallinnassa olevilla mailla, joilla valtion monikäyttömetsien inventointi tehtiin. Näin esimerkiksi Ilomantsissa on 124 kohdetta, jotka kaikki ovat hiilimiilualueita. Suomussalmen 60 kohteesta pääosa on hiilimiiluja ja loput raudanvalmistuspaikkoja. Metsähallituksen julkisten hallintotehtävien alueilla eli pääosin suojelualueilla sijaitsee puolestaan 181 kohdetta. Ne on inventoitu ulkoisesti rahoitetuissa hankkeissa ja Luontopalvelujen omana budjettirahoitteisena työnä muun muassa suojelualueiden hoito- ja käyttösuunnitelmien laatimista varten.

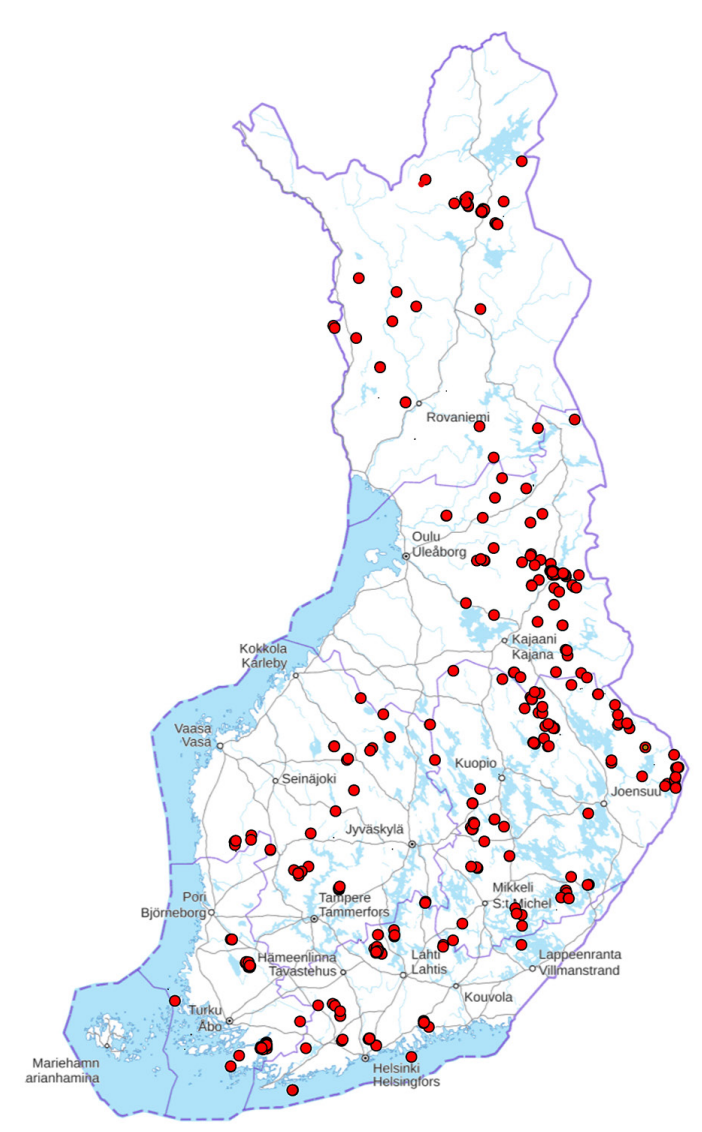

\section{Hiilimiilut}

Tarkasteltavista kohteista neljä viidesosaa on hiilimiiluja (Taulukko 1) eli paikkoja, joissa maa-aineksella peitettyjä puukekoja on palamislämmöllä kuivatislattu hiileksi ${ }^{11}$. Ruukkien puuhiilen kysyntä tuotti metsäisten seutujen talonpojille paljon työtä hiilenpoltossa. Laaja puuhiilen tuotanto jatkui 1600-luvulta aina 1800-luvun puoliväliin, jolloin ruukit ottivat käyttöön tehokkaat hiiliuunit ja hiilimiilujen polttaminen vähitellen hiipui.

Osa 664 hiilimiilukohteesta on tallennettu paikkatietojärjestelmään yksittäisiksi geometrialtaan pistemäisiksi kohteiksi, osa aluemaisiksi kohteiksi, joihin kuuluu enemmän kuin yksi hiilimiilu. Jälkimmäisiä on joka kymmenes kohde. Jos aluemaisten kohteiden yksittäiset miilut lasketaan yhteen, saadaan miilujen kokonaismääräksi 1092. Lukumääräisesti suurimmat hiilimiilualueet ovat Hämeenlinnan Valkjärvenkangas, jossa on 37 miilua ja Ilomantsin Kokkokangas 39 miiluineen. Hiilimiilu erottuu raporttien mukaan tyypillisesti tasalakisena pyöreänä maakumpareena, jonka läpimitta on luokkaa 8-22 metriä. Kumpareen ulkokehällä havaitaan usein kuoppia, jotka on tulkittu palamisen säätämistä varten tarpeellisiksi ilmanottoaukoiksi, toisinaan myös oja tai kaivanto. Aineistossa miilun tyyppiä ei ole määritelty systemaattisesti, mutta milloin tieto tyypistä on tallennettu, se on pystymiilu.

\footnotetext{
${ }^{11}$ Kangaskesti 2021.
} 


\begin{tabular}{|l|l|l|}
\hline Tarkenne & Kohteita & \% kaikista \\
\hline Hiilimiilut & 664 & 82.3 \\
\hline Kaivokset ja louhokset & 67 & 8.3 \\
\hline Kalkkiuunit & 13 & 1.6 \\
\hline Kullanhuuhdonnan jäännökset & 27 & 3.3 \\
\hline Raudanvalmistuspaikat & 31 & 3.8 \\
\hline Terva- ja tärpättitehtaat & 2 & 0.2 \\
\hline Vesisahat & 4 & 0.5 \\
\hline Yhteensä & 808 & 100.0 \\
\hline
\end{tabular}

Taulukko 1. Valtionmaiden teollisuusarkeologisten kohteiden tyypit PAVE-paikkatietojärjestelmässä.

Inventoiduista hiilimiiluista ei toistaiseksi ole ajoituksia käytettävissä. Monissa tapauksissa rakennelman päällä kasvavien puiden koosta inventoija on kuitenkin voinut päätellä, että kohteen käyttö on päättynyt reilusti yli sata vuotta sitten.

Kaikkiaan 19 tapauksessa on raportoitu hiilimiilun läheisyydessä jäännöksiä miilumajasta tai miilupirtistä, jossa miilunpolttajat ovat asuneet pitkään kestäneen työn aikana. Jäännökset erottuvat puolikaaren muotoisena tai suorakulmaisena maavallina, jossa on seinän tuntumassa tulisijan jäännökset. Tulisija on kylmämuurattu, joskus voi erottua tiiltäkin. Suuaukko on tyypillisesti miilua kohti. Tulisijan jäännökset ovat toisinaan ainoa säilynyt osa hiilimajasta, ja silloin on mahdollista pitää tulisijaa erheellisesti ns. ryssänuunina ${ }^{12}$. Alun perin miilumaja oli yksinkertainen riu'uista tai hirsistä koottu rakennelma tai paikoin maahan kaivettu korsumainen kuoppa. Havaintojen mukaan hiilimiilun läheltä löydetty maja voi kuitenkin olla kookaskin hirrestä salvottu kämppä. Paikoin hiilimiiluihin liittyy muita jäännöksiä, jotka on luokiteltu tervahaudaksi, kaivoksi, kellariksi, saunaksi tai kaskiröykkiöiksi.

\section{Kaivokset ja louhokset}

Kaivos- ja louhoskohteita on aineistossa 67. Ne edustavat 31 kaivos- tai louhosaluetta, joista useimmissa on louhittu karbonaattikiviä eli kalsiittia ja/tai dolomiittia. Kalkkia suosivan lajiston suojeluarvon takia monet karbonaattikivilouhokset on hankittu valtiolle luonnonsuojelun tarkoituksessa. Iäkkäin louhoksista on Pälkäneen (Luopioisten) Kukkian kalkkikivilouhos, joka palautuu 1500-luvulle. Perimätiedon mukaan sieltä olisi kuljetettu kalkkikiveä Hämeen linnaan rakennusmateriaaliksi. Kauko Puustisen aineiston ${ }^{13}$ mukaan Kukkiassa on louhittu kaikkiaan 4500 tonnia kalkkikiveä. Jäljellä on louhittuja 2-3 metrin korkuisia pystysuoria kallionpintoja. Niitä ei ole tutkittu tarkemmin ja ne ovat lisäksi kasvillisuuden peitossa. Kohde kuuluu Pirkanmaan maakuntamuseon adoptoituihin monumentteihin ja sitä hoidetaan muinaisjäännöskohteena.

\footnotetext{
12 Kangaskesti 2021, 151.

${ }^{13}$ Puustinen 2003. http://weppi.gtk.fi/aineistot/kaivosteollisuus/
} 




Kuva 2. Hiilimiilu Lähteensuo 2 Teijon kansallispuistossa. Miilunpohjaa ympäröi kaivanto. Kuva: Metsähallitus / Tapani Tuovinen, 2019.

Kuopion Huosiaisniemen dolomiittilouhos oli käytössä 1700-luvulta vuoteen 1916. Niemessä on louhittu kalkkia ainakin Juankosken ruukille. Ala-Siikajärven rannassa on noin 50 metriä pitkä avolouhos, jonka seinämät ovat pystysuorat.

Muita karbonaattikivilouhoksia ovat Vantaan Sottungbyn-Håkansbölen louhos (1800-luvulta) sekä Limskär (1840-luvulta, louhittu 30 tonnia kalkkikiveä Korppoon kartanoon) ja Âvensor, jotka sijaitsevat Paraisilla, entisessä Korppoossa. Åvensor mainitaan ensimmäisen kerran vuonna 1795 Johan Fredrik Glasbergin väitöskirjassa, joka tarkastettiin Turun vanhassa akatemiassa ${ }^{14}$. Kalkkikivi, jota tarvittiin Kalannin Männäisten ruukissa takkiraudan pelkistykseen, hankittiin Taivassalon Leikluodon talonpojilta. Leikluotolaiset vuorostaan ostivat kiven Åvensorista. Saarella toimi vuosina 1845-1956 louhos, jonka ympärille kehittyi parhaimmillaan 200 asukkaan yhdyskunta kansakouluineen ja kauppoineen. Kokonaistuotannoksi muodostui 100726 tonnia. Åvensor kuuluu Länsi-Turunmaan saaristoasutuksen RKY-alueeseen ${ }^{15}$.

Vimpelin Huosianmaankallio on kalkkikiven historian kannalta erityinen paikka, sillä siellä oli sekä teollista louhintaa että kansanomaista talonpoikaista kalkinpolttoa. Kalkkikivija dolomiittiesiintymä löydettiin vuonna 1836, ja sen teollinen louhinta on jatkunut meidän päiviimme asti, viimeisimpänä yrittäjänä Nordkalk Oy Ab. Huosiassa oli kalkkikiveä ja dolomiittia louhittu vuoteen 2003 mennessä 333934 tonnia $^{16}$.

Louhoksen alueella ja sen välittömässä läheisyydessä toimi vimpeliläisten sukulaisten ja naapurien muodostamia yhtiöitä, jotka louhivat kalkkikiveä ja polttivat sitä poltetuksi

\footnotetext{
${ }^{14}$ Glasberg 1795.

${ }^{15}$ Valtakunnallisesti merkittävät rakennetut kulttuuriympäristöt RKY. http://www.rky.fi/

${ }^{16}$ Puustinen 2003. http://weppi.gtk.fi/aineistot/kaivosteollisuus/
} 


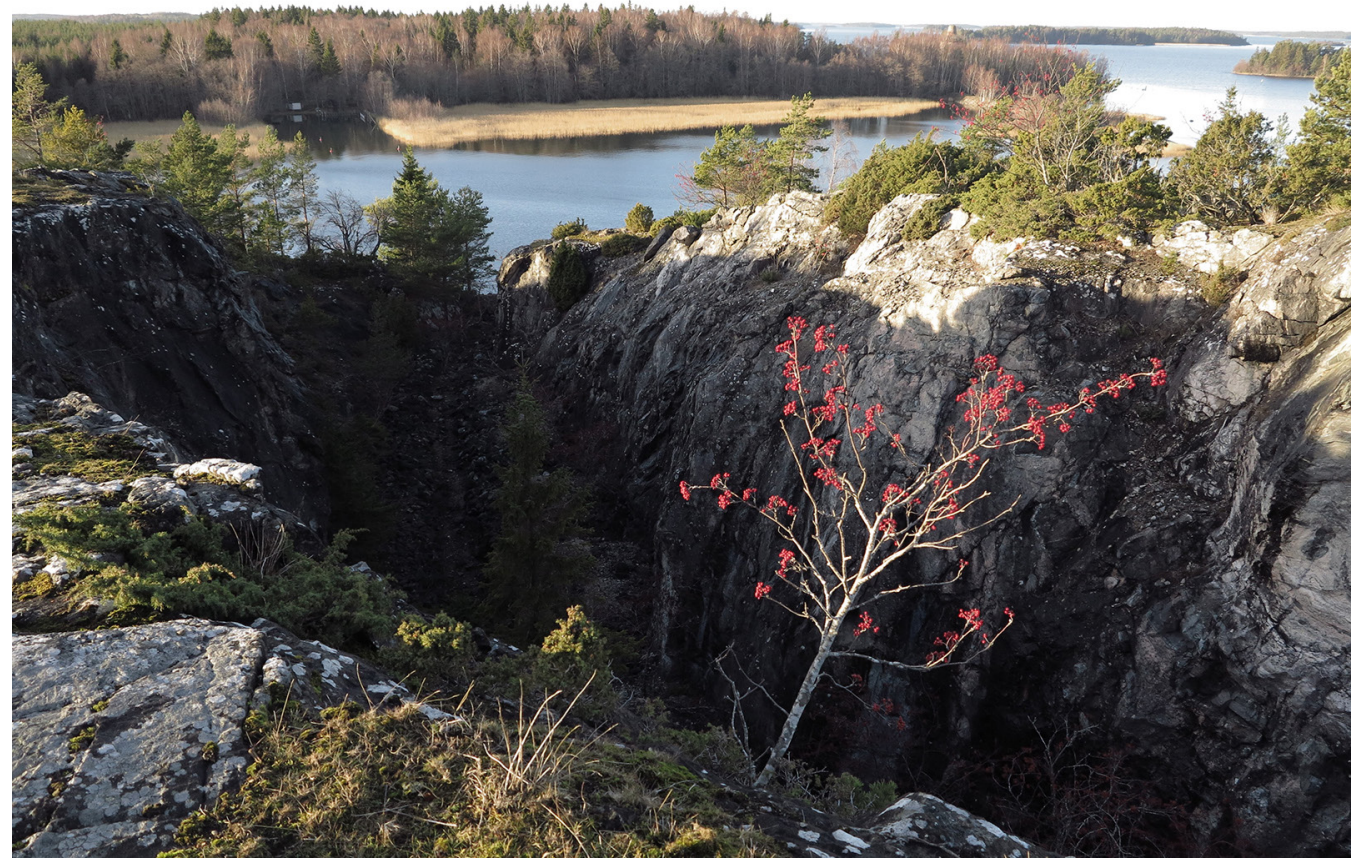

Kuva 3. Kirmon avolouhos Paraisten (Korppoon) Åvensorissa. Kuva: Tapani Tuovinen, 2017.

kalkiksi. Kalkinpolttajat käyttivät yksinkertaisia maauuneja, joissa oli lohkareilla vuorattu, edestä ja päältä avoin pesä. Siihen ladottiin poltettavat kalkkikivet ja niiden päälle holvattiin tulipesä kutakin polttoa varten. Tarvittava polttopuu haettiin lupaa vastaan valtionmetsästä. Valmis kalkki myytiin eri puolille maakuntaa. Toiminnan huippukausi ajoittui sotien jälkeiseen jälleenrakennusaikaan, jolloin muurauskalkilla oli paljon kysyntää ${ }^{17}$.

Kuopiossa Metsähallituksen hallintaan on tullut myös Laivonsaaren grafiittilouhos (1863-1917), Pisavuoren liuskekivilouhos ja hiekkakivilouhos sekä Pirunkellarin vuorikidelouhos (mainittu 1792). Kustavin Katanpään graniittilouhos, jossa vangit louhivat nupukiveä kadunpäällysteeksi vuosina 1931-1940, tuli Metsähallituksen hallintaan osaksi Selkämeren kansallispuistoa vuonna $2011^{18}$.

\section{Lauhanvuoren myllynkivikäsiteollisuus}

Lauhanvuoren kansallispuiston korkein kohta on $231 \mathrm{~m}$ korkea kupoli, joka jäi mannerjäätikön peräännyttyä runsaat 10000 vuotta sitten meren ympäröimäksi saareksi. Mannerjäätikkö, rantavoimat ja pakkasrapautuminen muodostivat Lauhanvuoren rinteille louhikkoja eli

\footnotetext{
${ }^{17}$ Peltonen 1998; Ylönen 1998.

${ }^{18}$ Katanpää. Kulttuuriperintöinventointi 2011. Metsähallitus, Arkeologiset inventointiraportit.
} 


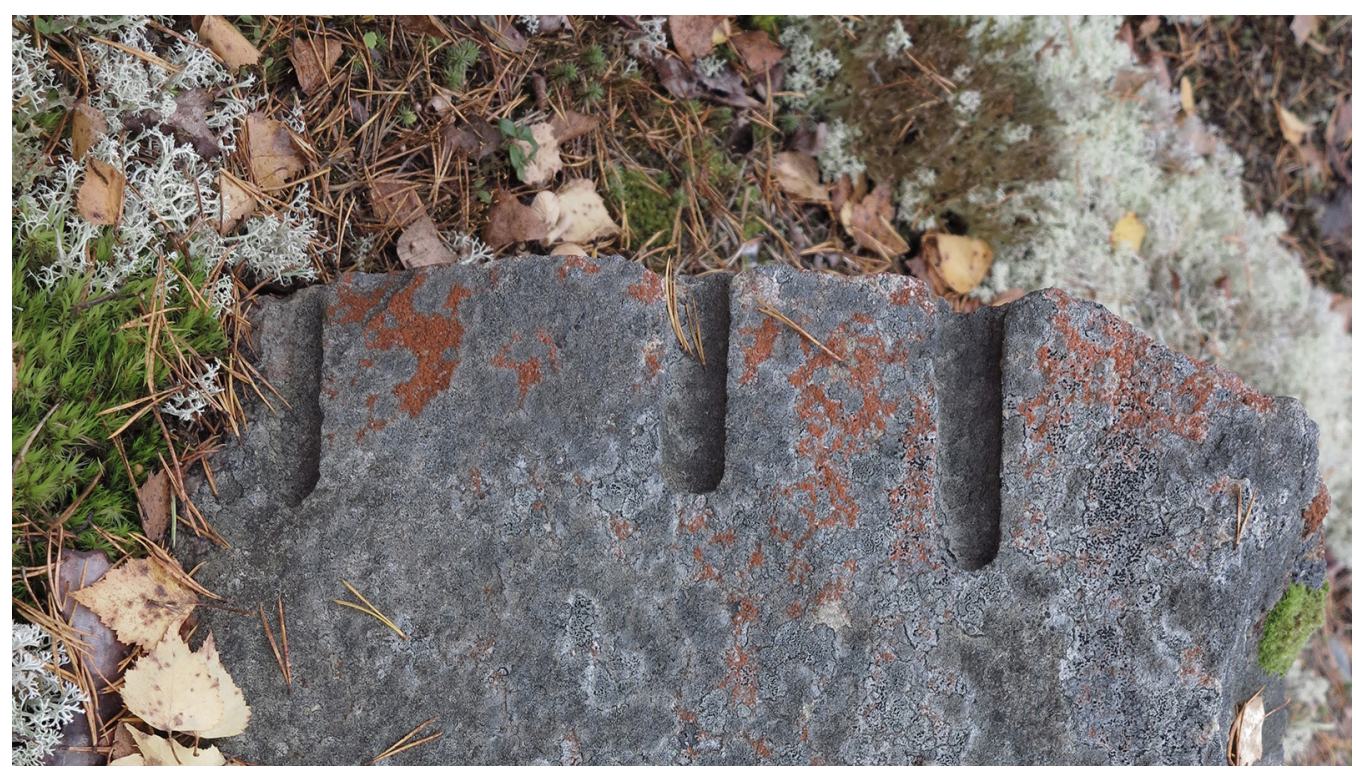

Kuva 4. Porausjälkiä myllynkiven aihiossa Kovanpruukinkivijatassa. Kuva: Metsähallitus / Tapani Tuovinen, 2017.

kivijatoja, jotka sisältävät myllynkiveksi sopivaa kovaa kvartsihiekkakiveä ${ }^{19}$. Inventoinnissa vuonna 2017 löydettiin jälkiä siitä, että kivijatoista ja niiden alapuolella hiekkakerrostumista on etsitty hiekkakiveä kaivamalla lapioilla. Geologi J.J. Sederholmin vuonna 1893 ottamasta valokuvasta nähdään, kuinka löydetty lohkare kangettiin puuseipään avulla ylös maasta (Kuva 5). Lohkareita muotoiltiin paikan päällä poraamalla ja lohkomalla. Maastosta löydetyistä aihioista voi arvioida, että valmiit myllynkivet olisivat painaneet noin $800 \mathrm{~kg}^{20}$.

Lauhanvuoren myllynkivikäsiteollisuus sai lähteiden mukaan alkunsa viimeistään vuonna 1857. Se on kuitenkin todennäköisesti vanhempaa perua, koska hyvää raaka-ainetta oli käytettävissä. Myllynkiven aihiot vietiin talvella rekikelillä viimeisteltäviksi Isojoelle tai Honkajoelle ja myytiin Etelä-Pohjanmaalle, Pohjois-Satakuntaan ja Tampereelle ${ }^{21}$. Myllynkiviä kaivettiin enenevästi 1880- ja 1890-luvuille asti, mutta sitten teollisesti valmistetut myllynkivet valtasivat nopeasti markkinat ja syrjäyttivät käsityön. Samalla tavalla tuotanto taantui myllynkivistään tunnetussa Säkylän pitäjässä, mutta hiukan aikaisemmin ${ }^{22}$.

\footnotetext{
${ }^{19}$ Salomaa 1982.

${ }^{20}$ Lauhanvuoren kansallispuisto. Suojelualueen kulttuuriperintökohteiden inventointi 2017. Metsähallitus, Arkeologiset inventointiraportit.

${ }^{21}$ Laine 2000, 24-25.

${ }^{22}$ Virrankoski 1963, 418.
} 




Kuva 5. Hiekkakivilohkare kaivetaan esiin hiekasta Lauhanvuorella. Kuva: J.J. Sederholm 1893, GTK:n Hakku-palvelu, Vanhatkuvat nro 696.

\section{Jussarön rautakaivos}

Vuonna 1834 löydettiin Jussarön saaren magnetiittiesiintymä nykyisessä Raaseporissa. Alueen kallioperän rautapitoisuus oli tunnettu jo kauan, koska se aiheutti voimakkaita häiriöitä alusten kompasseihin. Samana vuonna senaatti päätti vallata esiintymän valtion käyttöön. Louhinta aloitettiin välittömästi. Alusta alkaen kuitenkin korkeat tuotantokustannukset ja ulkomaankaupan rajoitukset aiheuttivat ongelmia, joita koetettiin ratkaista merkantilistisen talousopin pohjalta. Vuonna 1841 senaatin finanssitoimituskunnan päällikkö L.G. von Haartman, joka samoihin aikoihin vaikutti voimakkaasti valtion metsäpolitiikkaan, päätti kustannusten alentamiseksi käyttää kaivoksessa vankityövoimaa, aluksi irtolaisuudesta ja myöhemmin rikoksista tuomittuja. Enimmillään saarella oli majoitettuina 95 vankia ja 60 vartijaa, joten heitä oli enemmän kuin saarella oli vakituisia asukkaita. Huolimatta siitä, että tuotantoon investoitiin ja uusia kaivoskuiluja avattiin, toimintaa ei kuitenkaan saatu senaatin hinta- ja tuotantovaatimusten mukaiseksi. Lopulta senaatti lopetti kaivoksen toiminnan keväällä 1861 ja omaisuus huutokaupattiin²3.

${ }^{23}$ Laine 1929; Laine 1952; Sirén 2002. 


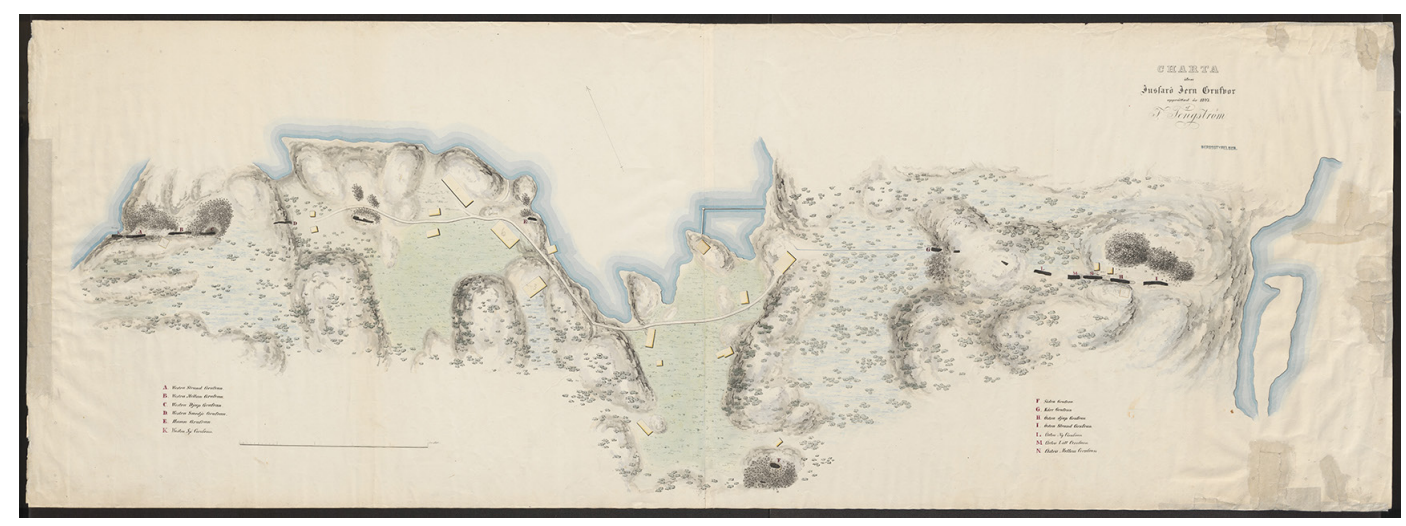

Kuva 6. Jussarön kaivosyhdyskunta vuonna 1843. Fredrik Tengströmin karttapiirros ${ }^{24}$.

Osa Jussaröstä kuuluu nykyään Tammisaaren saariston kansallispuistoon ja toisen osan saarta muodostaa Jussarön suojelumetsä. Alueella vuonna 2011 tehdyssä arkeologisessa inventoinnissa tärkeä tavoite oli saada maastohavainnot yhdistetyiksi säilyneeseen laajaan historialliseen lähdeaineistoon. Tärkein avain oli vuorihallituksen kaivostarkastajan Fredrik Tengströmin vuonna 1843 laatima kaivoskartta, johon hän merkitsi 13 kaivoskuilua ja 18 rakennusta (Kuva 6). Kaivoskuilut tulivat pääosin tunnistetuiksi, samoin osa lähteissä mainituista rakennelmista, muun muassa seitsemän hevosvintturia, joita käytettiin malmin ja veden nostoon kuiluista. Rakennusten jäännöksiä dokumentoitiin kuitenkin vain seitsemän - osaksi kaiketi siitä syystä, että rakennukset purettiin perusteellisesti huutokaupan jälkeen. Kaikkia säilyneitäkään rakennuksen jäännöksiä ei saatu tunnistetuiksi, sillä kaikki havaitut sijainnit eivät vastaa Tengströmin karttaa ${ }^{25}$.

Jussarön saaren itä-länsisuuntainen malmio on likimain pystysuorassa asennossa, joten avolouhinta eteni kallioperään suoraan alaspäin pystysuorin seinämin, jotka tulivat aina korkeammiksi louhinnan edetessä. Aikalaisraporttien mukaan kuiluista muodostui louhinnan aikana 60-140 jalkaa (18-42 m) pitkät ja 5-11 jalkaa (1-3 m) leveät. Tengströmin mukaan vuonna 1858 syvin kuilu oli 186 jalkaa eli $55 \mathrm{~m}$ syvä${ }^{26}$. Inventoinnissa mitattiin vedellä täyttyneitä kuiluista seitsemän syvyyttä välillä 7-38 m, keskimäärin $28 \mathrm{~m}$.

Vangit työskentelivät vuodesta 1840 alkaen ympäri vuoden. Talvikautta varten kuilut varustettiin katoksilla, mutta ne eivät ole voineet estää sadevettä valumasta kuiluun, puhumattakaan pohjaveden tihkumisesta, johon aikalaisraporteissa viitataan. Vangit louhivat ja erottelivat malmia kymmenien metrien syvyydessä pystysuorissa, ahtaissa, pimeissä ja märissä tai jäisissä kuiluissa. Vettä ja malmia kiskottiin hevoskiertoisilla vinttureilla ylös samoista kuiluista, joissa vangit louhivat. Olosuhteiden takia vankien keskuudessa vallitsi - kuten Ari Sirén on asian ilmaissut - epätoivoinen mieliala. Monet anoivat pääsyä siirtolaisiksi Sipe-

\footnotetext{
${ }^{24}$ Kansallisarkisto, Kauppa- ja teollisuushallituksen arkisto. K ja TH la.* 32:/- - Charta öfver Jussarö Jern Grufvor.

25 Jussarö. Kulttuuriperintöinventointi 2011. Metsähallitus, Arkeologiset inventointiraportit.

${ }^{26}$ Laine 1929.
} 
Kuva 7. Jussarö. Hevoskiertoisen vintturin pystysuora akseli tuettiin lohkareeseen porattuun koloon. Kuva: Metsähallitus / Tapani Tuovinen, 2011.
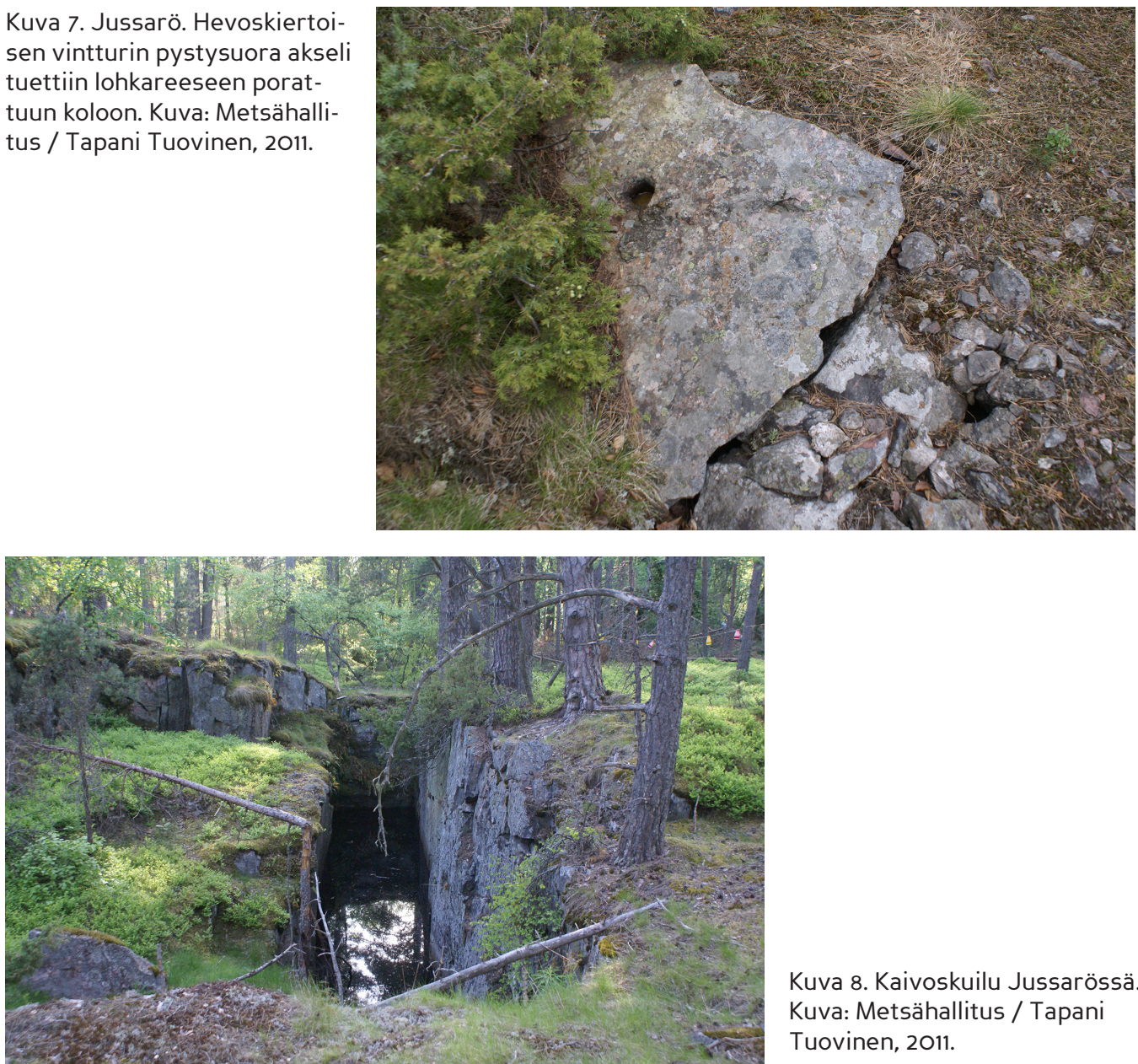

Kuva 8. Kaivoskuilu Jussarössä. Kuva: Metsähallitus / Tapani Tuovinen, 2011.

riaan, vaikka oli tiedossa, miten vaikeaa siellä oli päästä uuden elämän alkuun ${ }^{27}$. On myös tietoja tuotantolukujen alenemisesta vankien sairastelun takia ${ }^{28}$.

Valtiollisen kaivostoiminnan päätyttyä Jussarössä ja sitä ympäröivillä luodoilla yritettiin useita kertoja lähes sadan vuoden aikana elvyttää kaivostoiminta, mutta toiminta ei menestynyt. Oy Vuoksenniska Ab käynnisti lopulta vuonna 1954 mittavan teollisen kaivostoiminnan merenalaisessa malmiossa. Toiminta jatkui vuoteen 1967. Jussarön rautamalmin kokonaistuotannoksi on arvioitu 2000421 tonnia $^{29}$, josta valtion kaivoksen 1834-1861 osuus oli 31888 tonnia $^{30}$. Vanha kaivos tuotti toisin sanoen vain $1.6 \%$ kaikesta louhitusta malmista, vaikka kaivostyön inhimillinen hinta oli kohtuuton.

\footnotetext{
27 Juntunen 1983, 48-57.

${ }^{28}$ Sirén 2002, 30-33.

${ }^{29}$ Puustinen 2003. http://weppi.gtk.fi/aineistot/kaivosteollisuus/

${ }^{30}$ Sirén 2002, 32.
} 
Jussarön kaivoksen olot olivat kaikesta huolimatta osa 1800-luvun pakkotyölaitosten rangaistuskäytäntöjä. Vapausrangaistuksen tarkoitus oli parantaa rikollisen ihmisen kelvottomaksi katsottu persoonallisuus ja pakottaa hänet tottelevaiseksi eristämisen, tiukan kurin ja ankaran työnteon avulla ${ }^{31}$. Kaivoksen johtajat eivät voineet poiketa aikakauden vankeinhoidon näkemyksistä, semminkin kun he eivät olleet kaivos- tai vankeinhoitoalan ammattilaisia. Johtajat olivat senaatin talousosaston voimahahmon L.G. von Haartmanin tiukassa ohjauksessa, joten heidän vaikutuksensa kaivoksen toimintaan ja oloihin jäivät vähäisiksi32 Kaivostarkastaja Fredrik Tengström kävi saarella joitakin kertoja ja hänen tehtävänsä oli tehostaa kaivoksen teknistä toimivuutta. Hän oli - paitsi vuori-insinööri, kaivostarkastaja ja Suomen ensimmäisen kivipainon perustaja - myös yksi Lauantaiseuran jäsenistä, jotka kokoontuivat lauantai-iltaisin keskustelemaan kirjallisuudesta ja filosofiasta. Joukkoon kuuluivat J.V. Snellman, Zacharias Topelius, Elias Lönnrot, Fredrika Runeberg (Tengströmin sisko), J.L. Runeberg ja muita aikansa tunnettuja vaikuttajia. Tengströmin verkostot olivat seura- ja liike-elämässä. Ahdistava vankileiri oli hänelle etäinen paikka.

L.G. von Haartman oli kyllä kiinnostunut ja huolissaan Suomen vankeinhoidon tilasta ja maineesta. Hänellä oli valtaa, mutta hän ei vaatinut parannuksia vankiloiden oloihin, vaan hän paheksui moraalittomuuden ja kurittomuuden leviämistä vankiloissa. Erityinen syy hänen mukaansa oli se, että tutkintavangit pääsivät tekemisiin rangaistusta kärsivien vankien kanssa $^{33}$. Tämä ei ainakaan alkuun ollut tilanne Jussarössä.

\section{Kullanhuuhdonta}

Tarkasteltavista kohteista 27 liittyy kullanhuuhdontaan Inarissa ja Sodankylässä 1860-luvulla alkaneen kultaryntäyksen alkuvaiheesta alkaen. Kullanhuuhdonnasta on jäänyt maastoon kämppien jäännöksiä piisikiveyksineen ja valtausalueiden rajapyykkejä. Maaston muokkaamisen jäännöksiä havaittiin runsaasti. Kullanetsijät ovat kaivaneet maata, juoksuttaneet vettä ja kasanneet maamassoja. Heidän jäljiltään maastossa on makuoppia ja rakennelmia, kuten juoksutusojia, patoja, kivikenttiä, jätemaakasoja, huuhdontarännejä ja kylmämuurattuja eli rivinteerattuja pengerryksiä.

Dokumentoituja kullanhuuhdontakohteita on eniten Lapin vanhimman kultahistorian keskeisellä alueella Ivalojoen ja sen sivujokien varsissa, Sotajoella ja Pahaojalla. Ritakosken kämppäkartanolle perustettiin 1900-luvun alussa useiden kultayhtiöiden omistama höylä- ja sahalaitos huuhtomon uudisrakentamisen tarpeisiin. Sen voimanlähteenä toimi höyrykone, jonka jäännökset ovat säilyneet. Myös Pahaojalla on säilynyt höyrykone. Ivalojoella toimi valtion vuonna 1870 rakennuttama asema kullankaivuun valvontaa varten. Kullankaivajia ja muuta väkeä oli enimmillään satoja.

Lemmenjoen kansallispuiston alueella vaikuttanut kullankaivajayhteisö kuuluu kultahistorian myöhäiseen vaiheeseen, vuosiin 1945-1951, jolloin alueella toimi yli 200 kullankaivajaa. Tunnettuja arkeologiseksi luokiteltuja kohteita on Morgamojan ja Lemmenjoen varressa.

\footnotetext{
${ }^{31}$ Letto-Vanamo \& Ylikangas 1981, 62-69.

32 Laine 1929: 21-23.

${ }^{33}$ Kalleinen 2001, 198-205.
} 
Saariselällä Tolosjoen varressa on jäännökset vuosina 1902-1904 toimineen kullankaivuuyhtiö Prospektor Oy:n kultakaivoksesta ${ }^{34}$, jota kutsuttiin Ramsankaivokseksi. Siihen kuuluu kaksi kaivoskuilua ja kolmen hirsistä salvotun kämpän jäännökset sekä kaivantoja.

\section{Ruukit ja harkkohytit}

Tietokannassa raudanvalmistuspaikaksi luokiteltuja teollisuusarkeologisia kohteita ovat teolliset ruukkikompleksit, masuunit ja harkkohytit niihin liittyvine rakennelmineen.

Kirjakkalan ruukki nykyisessä Teijon kansallispuistossa Salossa (Perniössä) toimi vuosien 1686-1908 välisen ajan ${ }^{35}$. Se oli osa maaherra Lorenz Creutzin perustamaa Teijon ruukin kokonaisuutta. Kirjakkalan raudantuotanto kasvoi 1700-luvulla merkittäväksi ja paikalle syntyi ruukkiyhdyskunta. Ruukki tuotti kankirautaa erityisesti Teijon manufaktuurin raakaaineeksi. Kirjakkalassa toimi myös pajoja, joissa taottiin $\mathrm{mm}$. rautakankia, ankkureita ja rekien ja kärryjen osia.

Teijon raudantuotantoa ja varsinkin sen laajentamista rajoitti hiilen saanti. Teijon privilegiossa tosin taattiin ruukille yksinoikeus hiileen ruukin mailla ja ympäröivissä kylissä ${ }^{36}$. Maaherra oli vuonna 1760 velvoittanut talonpojat kahden peninkulman säteellä Teijosta hankkimaan ruukille puuta ja hiiltä, mutta päätöstä ei käytännössä noudatettu. Kun Teijon ruukki vuonna 1842 otti käyttöön hiiliuunit, tuotannon riippuvuus miilussa poltetusta hiilestä väheni tuntuvasti ${ }^{37}$.

Teijon ruukinmiljöö kuuluu valtakunnallisesti merkittäviin rakennettuihin kulttuuriympäristöihin ${ }^{38}$. Arkeologisina jäännöksinä on säilynyt harmaakivinen pato ja siitä masuuniin johtaneen vesikanavan jäännöksiä, rakennuksenjäännöksiä ja kuonaa. Teijon kansallispuistossa, jonka alue kattaa pääosin vanhat ruukinmetsät, on dokumentoitu 55 hiilimiilua ja hiilimajaa, joissa talonpojat polttivat hiiltä ruukin käyttöön. Suurin osa jäännöksistä on todennäköisesti peräisin ajalta ennen hiiliuunien käyttöönottoa.

Utajärven Kurimon ruukki sijaitsi Kiiminkijoen Kurimonkosken molemmilla rannoilla, soisella ja harvaan asutulla seudulla. Neljä oululaista porvaria sai luvan perustaa ruukin valtion tontille vuonna 1854. Tuotanto aloitettiin 1859. Kurimon masuunissa jalostettiin puuhiilellä paikallisesta järvimalmista raakarautaa. Vesikanava tuotti tarvittavan käyttövoiman. 1860-luvulla investoitiin kahteen putlausuuniin, hitsausuuniin, sulain-, kankirauta- ja nippuvasaraan, valssiin ja valimoon. Oulussa toimi ruukin oma myymälä. Tuotannossa satsattiin laadukkaisiin tuotteisiin, ja Moskovan teollisuusnäyttelyssä 1864 ruukin tuotteet saivat kiittävät arvostelut. Päätuotteena oli kankirauta ja sen lisäksi kehiteltiin teräksen valmistusta järvi- ja suomalmista. Ruukin alueelle rakennettiin yhdyskunta, johon kuuluivat tuotantorakennukset, ruukinpatruuna Axel Backmanin rakennuttama päärakennus, puutarha, työväen asunnot, työtupa, hiilivarasto, navetta ja koulu. Toiminnan ollessa laajimmillaan työntekijöitä oli 43. Lisäksi järvimalmin nosto työllisti ympäröivän alueen asukkaita ${ }^{39}$.

\footnotetext{
${ }^{34}$ Stigzelius 1987, 95-104, 112-115.

${ }^{35}$ Laine 1948, 232-287.

${ }^{36}$ Ekman 1937, 69, 117.

${ }^{37}$ Laine 1948, 245, 258-259.

${ }^{38}$ Teijon ruukinalue. Valtakunnallisesti merkittävät rakennetut kulttuuriympäristöt RKY. http://www.rky.fi/

${ }^{39}$ Laine 1948, 687-695; Kurimon ruukin vaiheita. http://www.kirjastovirma.fi/utajarvi/kurimo/
} 
Ruukin toiminta ajautui kuitenkin taloudellisiin vaikeuksiin. Syitä olivat vuosien 18671869 nälkävuodet, lainanhoitokustannusten nousu, kalliit kuljetukset veneillä ja pororaidoilla syrjäiseltä seudulta ja tulipalo vuonna 1868. Yritys myytiin Englantiin, mutta tuotantoa ei enää saatu kannattavaksi, vaan yritys teki uuden tulipalon jälkeen vararikon vuonna 1878 .

Tehtyjen havaintojen mukaan Kurimon maastossa on säilynyt jäännöksiä useimmista tuotantorakennuksista, vesikanavasta ja työväen asunnoista.

Metsähallituksen mailla tähän mennessä dokumentoidut harkkohytit sijaitsevat pääosin Kainuun ja Pohjois-Karjalan järviseuduilla. Niiden tuntomerkkeinä ovat peittyneet kivilatomukset, joissa on usein löydettävissä rautakuonaa. Harkkohytit ovat toisinaan pareittain ja niihin liittyy kuona- ja malmikasoja. Samaan kontekstiin kuuluu usein hiilimiilua, maakuoppia ja toisinaan tervahautakin. Harkkohytit lienevät luonteeltaan talonpoikaisia rakennelmia, joissa järvimalmia kuumennettiin puuhiilen lämmössä takoraudaksi. Samalla paikalla olisi myös poltettu tervaa. Rakennelmien ajoituksista ei inventoinneissa saatu sanottavasti tietoja.

\section{Savijärven ja Löytöjoen tervatehtaat}

Savijärven tervatehdas Hämeenlinnan Evon metsäopiston kruununpuistossa rakennettiin puun kuivatislauksen koelaitokseksi. Se edustaa varhaisinta tunnettua teollista toimintaa, jossa tervan tuotantoa pyrittiin uudistamaan uuden teollisen tekniikan avulla. Tarvittavat opit haki metsänhoitaja Erik Gabriel Sederholm opintomatkalla Saksassa vuosina 1856-1857. Tehdas perustettiin vuonna 1864. Säilyneiden tietojen mukaan tehtaan tuotanto oli kuitenkin pääosin hiiltä ja tervaa ja tärpättiä saatiin prosessin sivutuotteina. Toiminnan tarkkaa päättymisajankohtaa ei tunneta ${ }^{40}$.

Savijärvellä on maastossa säilynyt lohkokivestä kylmämuuratun kaksiosaisen retorttiuunin jäännökset ja mahdollinen rakennuksenjäännös. Paikalla on myös tiilistä muuratun tervauunin, mahdollisen mantteliuunin pohja, jonka halkaisija on noin 6 metriä. Puron rannalla on säilynyt puisen uittorännin maatuneita jäännöksiä ${ }^{41}$.

Löytöjoen tervatehdas sijaitsee Hyrynsalmella Löytöjoessa olevan kosken rannalla, lähellä Hallan erämaataloa. Tehtaan perustaja oli valtiopäivämies Johan Alfred Heikkinen eli Hallan Ukko, jääkäriliikkeen aktivisti ja monialainen yrittäjä. Hän ryhtyi 1880-luvulla suunnittelemaan tervanpolton kehittämistä ja hän sai kokeellisiin tervauunihankkeisiinsa teknistä apua oululaiselta insinööriltä Karl Löfhjelmiltä ja Teknillisen korkeakoulun professorilta Gustaf Kompalta. Monien vaiheiden jälkeen Heikkinen asettui maanviljelijäksi Hallaan ja perusti tervatehtaan vuonna 1924. Se oli toiminnassa vuoteen 1939 saakka.

Hallan Ukon tervatehdas edusti aikakautensa parasta tietämystä puun kuivatislaamisesta yksinkertaisissa olosuhteissa. Joen rannalla oli kolme metriä korkea luonnonkivistä muurattu uuni. Sen sisällä oli retortti, puun hiillyttämiskammio, joka tehtiin Oulujärvellä romutetun laivan runkopelleistä niittaamalla. Uuni lämmitettiin polttamalla tervaskantoja, jotka pilkottiin kirveellä tai kantopyssyllä räjäyttämällä. Retortti voitiin nostaa uunista nosturin avulla tyhjennystä ja täyttöä varten. Rantavajaan oli rakennettu pikiöljyn tislauskattila, joka jäähdytettiin sopivaan lämpötilaan höyrykoneen voimalla toimivan jäähdytyslaitteiston avulla. Jäähdytysvesi pumpattiin Löytöjoesta. Tervatehdas tuotti tervaa, tärpättiä, puuhappoa eli

\footnotetext{
40 Nykänen 2002, 28-29.

41 Taivainen 2016, 54-55.
} 
puuetikkaa, pikiöljyä ja saapasrasvaa. Tislauksessa syntyi myös alkoholia, jonka Heikkisen raittiusaatteen kannattajana väitetään määränneen kaadettavaksi maahan ${ }^{42}$.

Vuosina 1997-2000 Kainuun maaseutukeskus ry:n vetämässä Tervaprojektissa Löytöjoen rakennelmien raunioita tutkittiin ja restauroitiin. Retortille ja tärpättitislaamon jäännösten päälle rakennettiin suojakatokset, kivirakenteita vahvistettiin ja alueelle rakennettiin uudelleen nosturi, taukotupa ja silta ${ }^{43}$.

\section{Sahateollisuus}

Kirjakkalan ruukkiin kuului masuunin lisäksi vuonna 1760 perustettu vesisaha ja luumylly, jotka rakennettiin Sahajärvestä mereen laskevan jokiuoman varteen. Uoman yläpäässä on edelleen käytössä oleva jykevä luonnonkivistä rakennettu säännöstelypato, joka pitää Sahajärven pinnan 32 metrin tasolla. Vesisahan rakennutti ruukinomistaja Johan Jacob Kijk, jonka aikana ruukin tuotanto kasvoi ja ruukki menestyi myös karjataloudessa ja metsänhoidossa. Uomassa olevan patolammen rannoilla on ollut 1900-luvulla istutettu puisto.

Muuritutkimus Oy:n vuonna 2009 tekemässä tarkkuusinventoinnissa paikallistettiin 45 rakennelmaa, pääosin rakennuksen perustuksia, kylmämuurattuja kivirakennelmia ja pengerryksiä ${ }^{44}$.

Sulkavan Lohikosken vanhin tunnettu vesisaha perustettiin vuonna 1598 tai 1599. Sen jälkeen Lohikoskessa on toiminut useita vesisahoja vuodesta 1775 aina 1900-luvun alkuun asti. Maastossa on säilynyt saharakennusten jäännöksiä ja paikoin yli 10 metriä korkea metsittynyt sahajauhokasa.

\section{Metsähallituksen teollisuusarkeologinen kulttuuriperintö}

Metsähallituksen hallinnassa olevista teollisuusarkeologisista kohteista ruukit, kaivokset, louhokset ja vesisahat edustavat aikansa pääomavaltaisia teollisuushankkeita, joiden taustalla olivat yksityiset omistajat ja investoijat. Alun perin yksityismaille rakennetut teollisuuskohteet ovat myöhemmissä maakaupoissa siirtyneet valtion omistukseen ja Metsähallituksen käyttöön julkisten hallintopalvelujen tai metsätalouden taseessa. Merkittävimmät valtiovetoiset hankkeet olivat autonomian ajan Savijärven tervatehdas, joka rakennettiin Evon metsäopiston mallilaitokseksi, ja Jussarön rautakaivos, jossa senaatti toimi valtauksen antamalla mandaatilla; lisäksi 1930-luvulla Katanpää, joka toimi valtion vankisiirtolan kivilouhimona. Teollisten hankkeiden arkeologisiin jäännöksiin liittyy enemmän tai vähemmän laajaa historiallista lähdeaineistoa.

Useimpia Metsähallituksen maiden teollisuusarkeologisiksi luokitelluista kohteista voi luonnehtia anonyymeiksi, pysyvästi käytöstä poistuneiksi tai hylätyiksi ja niiden voi ainakin otaksua olevan iäkkäitä. Ne ovat olleet, toisin kuin teollisten laitosten jäännökset, tosiasiallisesti unohduksissa. Analyysi niiden valtionmaiden omistus- ja elinkeinohistoriasta, joilla

\footnotetext{
42 Juntunen 2002; Nykänen 2002.

${ }^{43}$ Luostarinen 2002.

${ }^{44}$ Teijon Sahajärven luonnonpuiston alueen rakennusarkeologinen inventointi v. 2009. Metsähallitus, Arkeologiset inventointiraportit.
} 
anonyymit teollisuusarkeologiset kohteet sijaitsevat, on jätettävä toiseen yhteyteen. Koska merkittävä osa kohteista sijaitsee Itä- ja Pohjois-Suomen pitäjissä, joissa valtion maanomistus oli merkittävä, varteenotettavana työhypoteesina voi kuitenkin pitää sitä, että anonyymit teollisuusarkeologiset kohteet sijaitsivat alun perin tyypillisesti valtionmailla. Yhden poikkeuksen muodostavat hiilimiilut Teijon ruukkiyhteisön takametsissä: ne siirtyivät valtion omistukseen vasta vuonna 1983.

Anonyymeja teollisuusarkeologisia kohteita ovat hiilimiilut, harkkohytit ja kullanhuuhdonnan jäännökset. Luen niihin myös kalkkiuunit ja Lauhanvuoren kivenottopaikat. $\mathrm{Ne}$ sijaitsivat metsissä ja vesistöjen varsilla ja niissä tuotettiin raaka-aineita, puolijalosteita tai tuotteita myyntiin tai edelleen jalostettaviksi. Näiden kohteiden merkitys on siinä, että ne avaavat arkeologisen näköalan takamaiden luonnonresurssien käyttöön ja edustavat sellaista varhaista teollisuutta, jossa valtion luonnonresurssit olivat keskeisessä asemassa.

Anonyymit teollisuusarkeologiset kohteet tuovat esiin myös toisen merkityksen: ne indikoivat tuotantoteknologioiden vanhentumista, joka kosketti etenkin takamailta hankittuja raaka-aineita, ja toisaalta tuotannon hankalia olosuhteita, jotka aiheutuivat muun muassa pitkistä kuljetusmatkoista ja karuista luonnonoloista. Äärimmäinen esimerkki ovat epävapaan työvoiman pitämisen pakkokeinot Jussarön rautakaivoksessa.

Metsähallituksen julkisten hallintotehtävien lakisääteisiin tehtäviin kuuluu kulttuuriomaisuuden vaaliminen. Kulttuuriomaisuuden arvottamisessa on ilmeinen merkitys sellaisilla alun perin valtion rakennuttamilla ja nyttemmin Metsähallituksen hallinnoimilla monumentaalikohteilla kuin esimerkiksi Kajaanin, Kuusiston ja Raaseporin rauniolinnoilla. Vaikka ne ovat päässeet raunioitumaan, ne ovat aina olleet näkyvillä ja yleisessä historiatietoisuudessa. Arkeologiset inventoinnit valtion metsissä ovat tuottaneet uutta tietoa sellaisesta näkymättömiin jääneestä valtion kulttuuriomaisuudesta, joka tulee näkyväksi vain määrätietoisella satsauksella kenttätyöhön. Samalla tunnetun kulttuuriomaisuuden kirjo on laajentunut.

Alueidenkäytön haitallisista vaikutuksista arkeologiseen kulttuuriperintöön on saatu enenevästi tutkimustietoa muun muassa Ulla Lähdesmäen perusteellisessa analyysissa Pirkanmaan makuntamuseon toimialueelta ${ }^{45}$. Metsähallituksen valtionmailla arkeologisiin kohteisiin kohdistuvat uhkat ovat vähäiset verrattuna muihin omistajaryhmiin. Kansallispuistoissa ja muilla Luontopalvelujen hallinnoimilla suojelualueilla arkeologiset kohteet ovat rauhoitettuja ihmisen toiminnalta siinä kuin luontokin. Periaatteessa sellaiset luonnonsuojeluun liittyvät työt kuin luonnonhoito (raivaus, poltto, laidunnus, aitaaminen jne.) ja palvelurakenteiden rakentaminen ja kunnossapito saattavat tulla koskemaan arkeologisia kohteita ja siksi suojelualueiden hallinnassa pyritään mahdollisuuksien mukaan ennakoivaan arkeologiseen inventointiin. Metsähallitus Metsätalous Oy:n hakkuissa ja maanmuokkauksessa noudatetaan ympäristöopasta, joka kieltää kajoamisen arkeologiseen kohteeseen riippumatta siitä, johtuuko muinaismuistolaista rajoituksia kohteen käsittelyyn ${ }^{46}$. Arkeologisten kohteiden säilyminen valtion mailla ja vesissä riippuu siten paljolti siitä, miten tarkasti alueet on inventoitu ja miten syvällisesti alueiden arkeologista kulttuuriperintöä tunnetaan ja ymmärretään. Metsähallituksen toiminnan merkitys ja vastuu arkeologisen kulttuuriperinnön suojelussa käy ilmeiseksi, kun katsoo karttaa: Metsähallituksen hallinnassa on liki kolmannes Suomen pinta-alasta.

\footnotetext{
45 Lähdesmäki 2018.

${ }^{46}$ Kaukonen et al. 2018, 68. https://julkaisut.metsa.fi/assets/pdf/mt/MH-ymparistoopas-2019.pdf.
} 


\title{
Lähteet
}

\author{
I Arkistolähteet \\ Kansallisarkisto, Helsinki \\ Kauppa- ja teollisuushallituksen arkisto. \\ Metsähallitus, Helsinki \\ Arkeologiset inventointiraportit.
}

\section{Il Painetut lähteet}

Bäckström, Lars. 2015. Svensk gruvrätt. En rättsvetenskaplig studie rörande förutsättningarna för utvinning av mineral. Luleå: Luleå tekniska universitet.

Ekman, Karl. 1937. Ett gammalt herrgårdsbruks historia. Tykö bruk 1686-1936. Helsingfors: Tykö Bruks Aktiebolag.

Glasberg, Johan Fredrik. 1795. Inledning Til Mineral-Historien Öfver Åbo Läns Norra Del. Åbo: Frenkellska Boktryckeriet.

Inger, Göran. 1997. Svensk rättshistoria. Malmö: Liber ekonomi.

Juntunen, Aapo. 1983. Suomalaisten karkottaminen Siperiaan autonomian aikana ja karkotetut Siperiassa. Suomen vankeinhoidon historiaa 3. Helsinki: Oikeusministeriön vankeinhoito-osasto.

Juntunen, Kalle. 2002. "Hallan Ukon tervauunit". Teoksessa Hallan tervaa. Hallan Ukon terva- ja tärpättitehdas Hyrynsalmi, Löytöjoki. Restaurointiraportti 1997-2001, toimittanut Panu Nykänen: 44-51. Helsinki: Museovirasto, Kainuun maaseutukeskus, Kainuun Museo, Polyteekkarimuseo ja Tekniikan Historian Seura ry.

Jutikkala, Eino. 1958. Suomen talonpojan historia. Suomalaisen Kirjallisuuden Seuran Toimituksia 257. Helsinki: Suomalaisen Kirjallisuuden Seura.

Kalleinen, Kristiina. 2001. Isänmaani onni on kuulua Venäjälle. Vapaaherra Lars Gabriel von Haartmanin elämä. Suomalaisen Kirjallisuuden Seuran Toimituksia 815. Helsinki: Suomalaisen Kirjallisuuden Seura.

Kallio, Titta. 2005. "Teollisuusarkeologiaa Suomessa: tutkimustapoja ja -ongelmia". Tekniikan Waiheita, 3/2005: 40-50.

Kangaskesti, Janne. 2021. Miilunpoltosta ja hiilimiiluista Suomessa. Tekniikan Waiheita, 3/2021: 140-159.

Laine, Eevert. 1929. "Jussaaren rautakaivos valtion käyttämänä vuosina 1834-1861". Historiallinen arkisto, 37, 3 : $1-70$.

Laine, Eevert. 1948. Suomen vuoritoimi 1809-1884. II. Ruukit. Historiallisia tutkimuksia, 31, 2. Helsinki: Suomen Historiallinen Seura.

Laine, Eevert. 1952. Suomen vuoritoimi 1809-1884. III. Harkkohytit, kaivokset, konepajat. Historiallisia tutkimuksia, 31, 3. Helsinki: Suomen Historiallinen Seura.

Laine, Sirkku. 2000. Elämisen ehdot Lauhanvuoren ja Haapakeitaan tuntumassa. Metsähallituksen luonnonsuojelujulkaisuja A 116. Vantaa: Metsähallitus.

Letto-Vanamo, Pia ja Heikki Ylikangas. 1981. "Hajapiirteitä laillisen vapaudenriiston ja sen toimeenpanon kehityksestä esiteollisena aikana". Teoksessa Katsauksia vankeinhoidon kehitykseen, toimittanut Esa Suominen: 37-84. Suomen vankeinhoidon historiaa 1. Helsinki: Oikeusministeriön vankeinhoito-osasto.

Luostarinen, Maria. "Korjaussuunnittelu ja raunioiden suojaus". Teoksessa Hallan tervaa. Hallan Ukon tervaja tärpättitehdas Hyrynsalmi, Löytöjoki. Restaurointiraportti 1997-2001, toimittanut Panu Nykänen: 72-79. Helsinki: Museovirasto, Kainuun maaseutukeskus, Kainuun Museo, Polyteekkarimuseo ja Tekniikan Historian Seura ry.

Lähdesmäki, Ulla. 2018. Muinaisjäännös ympäristön muutoksessa. Modernin alueidenkäytön vaikutuksia Pirkanmaan muinaisjäännöskantaan. Karhunhammas 18. Turku: Turun yliopisto.

Nykänen, Panu. 2002. "Suomalaisen tervateollisuuden historia". Teoksessa Hallan tervaa. Hallan Ukon tervaja tärpättitehdas Hyrynsalmi, Löytöjoki. Restaurointiraportti 1997-2001, toimittanut Panu Nykänen: 21-43. Helsinki: Museovirasto, Kainuun maaseutukeskus, Kainuun Museo, Polyteekkarimuseo ja Tekniikan Historian Seura ry.

Parpola, Antti ja Veijo Åberg. 2009. Metsävaltio: Metsähallitus ja Suomi 1859-2009. Helsinki: Edita. 
Peltonen, Karim. 1998. "Kun piru itse hyppäsi piisistä. Vimpelin seudun talonpoikainen kalkinpoltto arkeologisena ilmiönä". Tekniikan Waiheita, 1/1998: 17-23.

Salomaa, Risto. 1982. Post Glacial Shoreline Displacement in the Lauhavuori Area, Western Finland. Annales Academiæ Scientiarum Fennicæ, A III 134: 81-97.

Sirén, Ari. 2002. Jussarö: luotsi- ja kaivosyhteisö Tammisaaren ulkosaaristossa. Metsähallituksen luonnonsuojelujulkaisuja Sarja A n:0 40. 3. painos. Vantaa: Metsähallitus.

Stigzelius, Herman. 1987. Kultakuume: Lapin kullan historia. 2. painos. Helsinki: Suomen matkailuliitto.

Taivainen, Jouni. 2016. Metsiin kadonneet. Valtion metsien kulttuuriperintökohteiden inventointi 2010-2015. Metsähallituksen metsätalouden julkaisuja n:o 73. Helsinki: Metsähallitus.

Talvitie, Petri. 2013. Kyläosuudesta yksityiseen maanomistukseen. Isojako Länsi-Uudellamaalla 1700-luvulla. Historiallisia tutkimuksia Helsingin yliopistosta 28. Helsinki: Helsingin yliopisto.

Virrankoski, Pentti. 1963. Myyntiä varten harjoitettu kotiteollisuus Suomessa autonomian ajan alkupuolella (1908 - noin 1865). Historiallisia tutkimuksia LXIV. Helsinki: Suomen Historiallinen Seura.

Ylönen, Raija. 1998. "Kalkinpoltto kotiteollisena sivuelinkeinona Vimpelissä". Tekniikan Waiheita, 1/1998: 13-16.

\section{Internet}

Arkeologisen kulttuuriperinnön opas. http://akp.nba.fi/ [luettu 16.8.2021]

Kurimon ruukin vaiheita. http://www.kirjastovirma.fi/utajarvi/kurimo/ [luettu 16.8.2021]

Kaukonen, Maarit \& Timo Eskola, Ilkka Herukka, Hanna Karppinen, Lauri Karvonen, Ilkka Korhonen, Panu Kuokkanen ja Asta Ervola. 2018. Metsähallitus Metsätalous Oy:n ympäristöopas. 2. korj. painos. https:// julkaisut.metsa.fi/assets/pdf/mt/MH-ymparistoopas-2019.pdf [luettu 16.8.2021]

Puustinen, Kauko. 2003. Suomen kaivosteollisuus ja mineraalisten raaka-aineiden tuotanto vuosina 15302001. Historiallinen katsaus erityisesti tuotantolukujen valossa. Geologian tutkimuskeskus, arkistoraportti, M 10.1/2003/3. Espoo: Geologian tutkimuskeskus. http://weppi.gtk.fi/aineistot/kaivosteollisuus/ [luettu 16.8.2021]

Uljas-tietojärjestelmät. https://www.metsa.fi/maat-ja-vedet/paikkatieto/paikkatietojarjestelmat/ [luettu 16.8.2021]

Valtakunnallisesti merkittävät rakennetut kulttuuriympäristöt RKY. http://www.rky.fi/ [luettu 16.8.2021] 